\title{
Profilin, a Change in the Paradigm
}

\author{
Rodríguez del Río $\mathrm{P}^{1,2}$, Díaz-Perales $A^{3,4}$, Sánchez-García $S^{1,2}$, Escudero $C^{1,2}$, Ibáñez $M D^{1,2}$, \\ Méndez-Brea $\mathrm{P}^{1,2,5}$, Barber $\mathrm{D}^{6}$
}

\author{
${ }^{1}$ Allergy Department, Hospital Infantil Universitario Niño Jesús, Madrid, Spain \\ ${ }^{2}$ Health Research Institute Princesa, Madrid, Spain \\ ${ }^{3}$ Center for Plant Biotechnology and Genomics (UPM-INIA), Pozuelo de Alarcon, Madrid, Spain \\ ${ }^{4}$ Department of Biotechnology and Plant Biology, ETSIAAB, Technical University of Madrid, Spain \\ ${ }^{5}$ Allergy Department, Complejo Hospitalario Universitario de Santiago, Santiago de Compostela, Spain \\ ${ }^{6} I M M A$, Facultad de Medicina, Universidad CEU San Pablo, Madrid, Spain
}

J Investig Allergol Clin Immunol 2018; Vol. 28(1): 1-12

doi: 10.18176/jiaci.0193

\section{Abstract}

Profilin is a protein that is present in all eukaryotic cells and is responsible for cross-reactivity between pollen, latex, and plant foods. It has been classically acknowledged as a minor or nearly irrelevant allergen, although recent data are changing this conception. The objective of this manuscript is to provide a comprehensive review of published data on the role of this ubiquitous allergen in pollen, latex, and plant food allergy.

The patterns of recognition of this minor allergen follow a north-south gradient. Although present in all pollens and vegetables, profilin is significantly associated with allergy to grass pollen and to Cucurbitaceae fruits. Heb v 8, the latex profilin, is usually a marker of profilin allergy in plant food-allergic patients, although it has no clinical relevance in latex allergy. Sensitization to profilin jeopardizes the diagnosis of pollen allergy and selection of immunotherapy, and although component-resolved diagnosis can identify its impact, there are no tailored treatments available. In recent years, several new publications have shown how profilin should be taken into account and, under certain circumstances, considered a marker of severity, an allergen capable of inducing respiratory symptoms, and, in its natural purified form, a potential candidate for etiological treatment of food allergy.

Current data on profilin strongly support the need for a shift in the previously accepted paradigm for this allergen. More research should be done to assess the real clinical impact of sensitization in specific populations and to develop therapeutic strategies.

Key words: Profilin. Phl p 12. Bet v 2. Allergy. Food allergy. Asthma. Immunotherapy. Allergen.

\section{Resumen}

La profilina es una proteína presente en todas las células eucariotas, siendo responsable de la reactividad cruzada entre polen, látex y alimentos vegetales. Ha sido reconocida clásicamente como un alérgeno menor o irrelevante; sin embargo, datos recientemente publicados están modificando esta interpretación. El objetivo de este manuscrito es realizar una revisión comprensiva de la literatura sobre el papel de este ubicuo alérgeno en el polen, látex y los alimentos vegetales.

El patrón de reconocimiento de este alérgeno menor sigue un gradiente de norte a sur, y a pesar de estar presente en todos los pólenes y vegetales, está significativamente asociado al polen de gramíneas y a las frutas de la familia Cucurbitaceae. Heb v 8, la profilina del látex, es habitualmente un marcador de alergia a profilina en pacientes alérgicos a vegetales pero sin relevancia clínica en la alergia a látex. La presencia de la sensibilización a profilina dificulta el diagnóstico de alergia a pólenes y la selección de la inmunoterapia, y a pesar de que el diagnóstico por componentes puede identificar su impacto, no existen tratamientos personalizados disponibles. En los últimos años, diversas publicaciones nuevas han demostrado como la profilina debe ser tenida en cuenta y considerada bajo determinadas circunstancias, como un marcador de gravedad, como un alérgeno capaz de inducir síntomas respiratorios, y en su forma natural purificada, como un potencial candidato para realizar un tratamiento etiológico para tratar la alergia a alimentos.

El conocimiento actual sobre la profilina impulsa la necesidad de cambiar el concepto que previamente se tenía sobre este alérgeno. Sería preciso investigar más para valorar el impacto clínico real de esta sensibilización en poblaciones específicas y desarrollar estrategias terapéuticas.

Palabras clave: Profilina. Phl p 12. Bet v 2. Alergia. Alergia a alimentos. Asma. Inmunoterapia. Alérgeno. 


\section{Introduction}

Profilins are 12 to $16-\mathrm{kDa}$, actin monomer-binding proteins expressed in specific viruses and in all eukaryotic cells, with the exception of some protists $[1,2]$. Profilins promote polymerization of actin filaments and monomers and are thus involved in the generation of the cytoskeleton and in movement [1]. Their role in such essential processes explains their ubiquitous expression and high levels of conservation [3] (Figure). The identification of 50 additional profilin ligands suggests an important role in many more complex molecular processes, as well as in signal transduction $[2,4]$. The first allergenic profilin described, Bet v 2 from birch pollen, was identified in 1991 [5], and since then, many allergenic profilins have been identified in pollen, plant foods, and latex [6], thus indicating a high degree of cross-reactivity due to their common epitopes.

Some sequential and conformational profilin B-cell epitopes have been described using various approaches. The actin-binding site and the adjacent plant-specific pocket were found to comprise an immunogenic region responsible for cross-reactivity in the Arabidopsis profilin [7]. Two regions overlapping with the actin-binding site were identified as major cross-reactive epitopes, and a third site, consisting of residues 30-50, was found to be a likely cause of extensive cross-reactivity in birch profilin [8]. Several epitopes, which in fact cover most of the surface, have been identified in model structures of several profilins. Radauer et al [9] highlighted 3 main candidates: epitope 1, SWQTYVDDHQYQGL; epitope 7, PGAMVIQGEPGARGKPNE; and epitope 8, MKDEPGHVIQGEPGARKE. Leitner et al [10] found that the circular peptide CAISGGYPVC inhibited IgE binding to mugwort pollen, birch pollen, and celery tuber profilin and speculated that this epitope might be an important epitope in plant profilins. In the case of $\mathrm{Cuc} \mathrm{m} 2$, the main watermelon allergen, the sequence S2W3A5Y6D9H10T111P112G113Q114 N116M117R121L122 [11] was described as the main epitope. This IgE-binding region was implicated in cross-reactivity with most plant profilins (eg, Phl p 12 and Bet v 2) owing to the high identity observed (Table 1). The identification of this sequence allows it to be used as a diagnostic marker for cross-reactivity mediated by the profilin family, as well as for future strategies in immunotherapy.

\section{The Established Concept of Profilin}

\section{Prevalence}

In order to establish the prevalence of profilin, it is extremely important to clarify whether the selected population is first chosen for its pollen allergy or plant food allergy. Profilin sensitization ratios across Europe can vary widely among pollen-allergic patients, especially primary sensitizers, from $5 \%$ in a Swedish birch pollen-allergic cohort [12] to $51 \%$ in a subset of a Mercurialis annua-allergic population in Spain [13]. This geographical variability and north-south gradient is due to the predominance of various pollens across Europe [14], which has been corroborated elsewhere [3].

Profilin sensitization is assumed to be always preceded by sensitization to a major allergen, although cross-sectional studies have failed to identify the primary sensitizer in most panallergensensitized patients because the vast majority are sensitized to 2 or more pollen sources [15]. Grass pollen has been reported to be one of the more robustly associated profilin sensitizers [16].
A
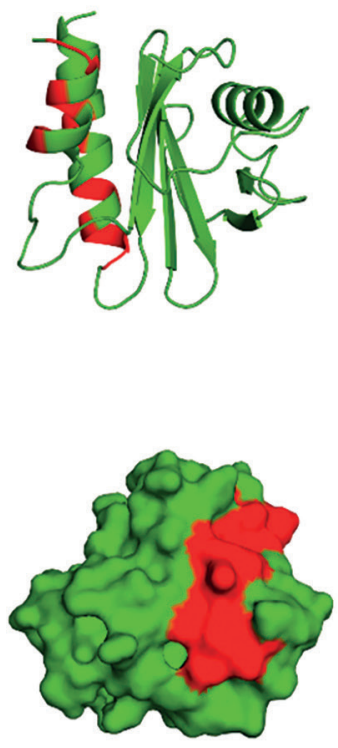

B
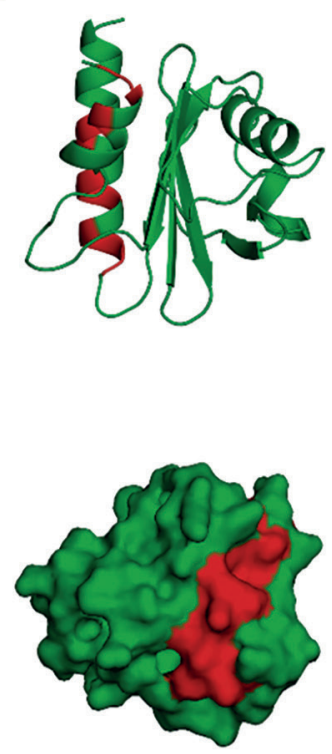

C
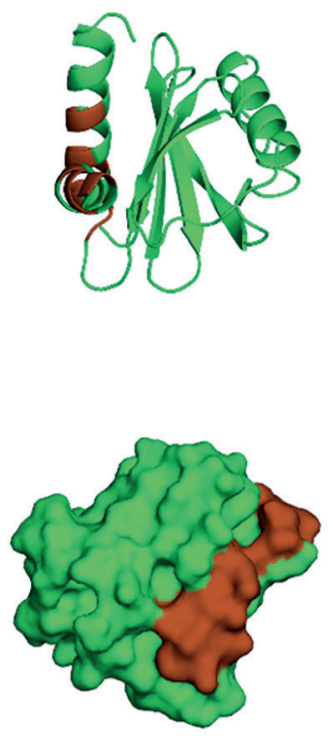

D
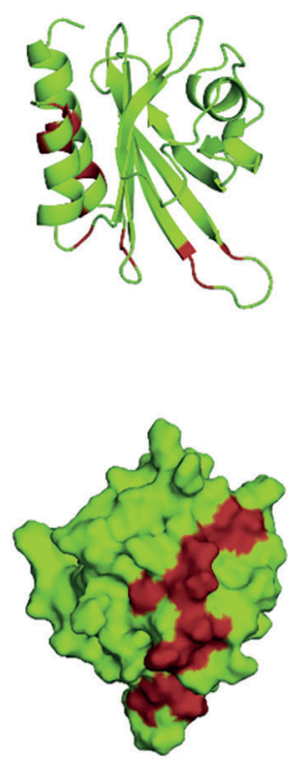

Figure. 3D structures of melon Cuc m2 (A), timothy grass pollen Phl p 12(B), birch pollen Bet v 2 (C), and human I profilins (D) [5]. Upper row: molecular surfaces in the upper orientation. Bottom row: views derived from the upper row after a clockwise $90^{\circ}$ rotation about a vertical axis. Only the differences with respect to the sequence in $\mathrm{A}$ are labelled in mimotope sequences in B and $\mathrm{C}$. 
Table 1. Members of the Profilin Family Identified as Allergens ${ }^{a}$

\begin{tabular}{|c|c|c|c|}
\hline Plant Species & Allergen Name & Id $(\%)$ & UNIPROT \\
\hline Cucumis melo (muskmelon) & Cuc m 2 & 100 & Q5FX67 \\
\hline Actinidia deliciosa (kiwi fruit) & Act d 9 & 68 & FG438715 \\
\hline Ambrosia artemisiifolia (short ragweed) & Amb a 8 & 69 & Q2KN24 \\
\hline Ananas comosus (pineapple) & Ana c 1 & 76 & Q94JN2 \\
\hline Apium graveolens (celery) & Api g 4 & 78 & Q9XF37 \\
\hline Arachis hypogaea (peanut) & Ara h 5 & 79 & Q9SQI9 \\
\hline Artemisia vulgaris (mugwort) & Art v 4 & 69 & Q8H2C9 \\
\hline Betula verrucosa (Betula pendula) (European white birch) & Bet v 2 & 74 & P25816 \\
\hline Capsicum annuum (bell pepper) & Cap a 2 & 85 & Q93YI9 \\
\hline Chenopodium album (pigweed) & Che a 2 & 77 & Q84V37 \\
\hline Citrus sinensis (sweet orange) & Cit s 2 & 76 & P84177 \\
\hline Corylus avellana (hazel) & Cor a 2 & 83 & Q9AXH5 \\
\hline Daucus carota (carrot) & Dau c 4 & 75 & Q8SAE6 \\
\hline Glycine max (soybean) & Gly m 3 & 83 & O65809 \\
\hline Helianthus annuus (sunflower) & Hel a 2 & 71 & O81982 \\
\hline Hevea brasiliensis (para rubber tree [latex]) & Hev b 8 & 82 & O65812 \\
\hline Malus domestica (apple) & Mal d 4 & 77 & Q9XF42 \\
\hline Olea europaea (olive) & Ole e 2 & 74 & O24169 \\
\hline Phleum pratense (timothy grass) & Phl p 12 & 76 & P35079 \\
\hline Phoenix dactylifera (date palm) & Pho d 2 & 77 & Q8L5D8 \\
\hline Prunus persica (peach) & Pru p 4 & 79 & Q8GT40 \\
\hline Pyrus communis (pear) & Pyr c 4 & 77 & Q9XF38 \\
\hline Salsola kali (Russian thistle) & Sal k 4 & 76 & C6JWH0 \\
\hline Sinapis alba (yellow mustard) & Sin a 4 & 81 & E6Y2M0 \\
\hline Solanum lycopersicum (tomato) & Sola 11 & 85 & Q93YG7 \\
\hline
\end{tabular}

aSequence identity to Cuc $\mathrm{m} 2$ is indicated.

Barber et al [17] used a panel of 13 purified allergens to study 891 pollen-allergic patients from southern Spain, of whom 15\% were sensitized to apple profilin ( $\mathrm{rMal} \mathrm{d} 4$ ). More interestingly, a geographical variation according to seasonal grass pollen load was observed, revealing areas in which $50 \%$ of the population was sensitized to profilin. A logistic multivariate analysis showed that profilin sensitivity was associated with the major grass allergens Phl p 1 (OR, 3.16; 95\%CI, 1.71-5.83) and Phl p 5 (OR, 6.19; 95\%CI, 3.86-9.91). In a study with a similar design, but in 1329 patients from northern Spain, the same authors [18] detected that $18.8 \%$ of the population was profilin-sensitive and found that this sensitivity was again significantly associated with Phl p 5 (OR, 5; CI not provided). As a consequence, profilin seems to play a relevant role in areas where grass allergy is predominant. These areas can be identified using epidemiological studies mapping the sensitization clusters by region, such as that of Barber et al [19] in Spain.

The role of pollens other than grass in profilin sensitization can be understood with the olive pollen allergy model, as this pollen reaches maximum known exposure levels in some areas of Andalucía [17]. In the case of olive profilin (Ole e 2), results for prevalence and impact of sensitization are contradictory. Ole e 2 is usually acknowledged as a minor allergen [20] and was not found to be associated with Ole e 1 in one of the aforementioned studies [17]. Moreover, this lack of association has already been the subject of commentary by other authors [21]. However, in the study by Quiralte et al [22], $54 \%$ of 146 olive-allergic patients displayed sIgE to Ole e 2. The authors speculate that given the extremely heavy load of olive pollen in the area studied (Jaen, Spain, average 500 to 1000 grains $/ \mathrm{m} 3$ with peaks of 10000 grains $/ \mathrm{m} 3)$, the patients may have become sensitized to more olive allergens than in other places, thus underscoring the relevance of the area in the patients' molecular recognition patterns. One potential weakness of this study is the lack of information regarding the patients' sensitization to other pollen sources. This heavy pollen load was also used to explain relevant sensitization to other minor olive allergens, especially Ole e 7, which was found to be linked to an increase in the prevalence of asthma and the severity of allergic disease $[17,23]$. 
On the other hand, if patients are selected based on plant food allergy as the main criterion, the geographical distribution of profilin sensitization displays a similar northsouth gradient. In an interesting study by Fernandez-Rivas et al [24], component-resolved diagnosis (CRD) was used to assess area-dependent recognition patterns for Mal d 1 (major apple allergen, Bet v 1 homologue), Mal d 2 (thaumatin like protein), Mal d 3 (lipid transfer protein [LTP]), and Mal d 4 (profilin) in a group of 389 apple-allergic patients from 4 European countries (Austria, Italy, Netherlands, and Spain). Their results showed that apple allergy in individuals from the Netherlands, Austria and Italy was associated with Mal d 1 and milder symptoms, whereas in Spain, apple allergy was linked to Mal d 3 and severe manifestations. Both sensitization to and sIgE levels of profilin were higher in Spain and Italy (around $40 \%$ and $30 \%$ of patients, respectively) than in the Netherlands or Austria, where it was recognized in no more than $15 \%$ of the population. This study provides further evidence of the higher prevalence of profilin sensitization in southern countries than in northern countries, a trend that is also supported by Andersen et al [25] in their review of the panallergens involved in Rosaceae fruit allergy. After including 38 European studies with determination of several isolated allergens, the authors state that in western Mediterranean areas, sensitization to PR10 is almost absent, with LTP being the first cause of Rosaceae fruit allergy, followed by profilin, which is also linked to nonRosaceae fruits. In contrast, in northern and central Europe, Rosaceae fruit allergy is mostly due to class 2 fruit allergy and cross-reactivity to PR-10 (Bet v 1 homologs) with poorer profilin recognition.

\section{Diagnosis of Sensitization to Profilin}

Profilin allergy can be diagnosed either in vitro or, in the countries where purified profilin extract is available, in vivo. In vivo diagnosis with purified palm tree profilin, nPho $\mathrm{d} 2$, at $50 \mu \mathrm{g} / \mathrm{mL}$, has proven to have a high diagnostic efficiency [18,26-29]. For in vitro profilin diagnosis, a single profilin (either Bet v 2 or Phl p 12) is sufficient [26]. Variability in the recognition of profilin in in vitro diagnosis is more related to specific isoform selection and protein folding than to real recognition differences between the various allergenic sources [26]. A recent consensus document examines the use of molecular diagnosis in allergy in daily practice, including a chapter on profilin and its characteristics [30].

\section{The Role of Profilin in Respiratory Allergy}

Profilin has been accepted as a minor aeroallergen in most pollen sources [31], with little or no clinical impact and a prevalence below $50 \%$ in most cases. There are some exceptions, such as Che a 2, the Chenopodium album profilin, which was recognized by $55 \%(n=104)$ of a Spanish Chenopodium-allergic population [32]. However, its clinical impact was not fully addressed since the same group was also sensitized to Che a $3(46 \%)$ and displayed bands for several other molecular weights in Western blots from a sample of 12 patients. Its role as a major allergen in this pollen was later supported in a population of 32 Chenopodium-allergic patients from Iran, where $81 \%$ displayed $\mathrm{IgE}$ to rChe a 2 [33]. Another example of profilin as a major allergen is that of
Pho d 2, which triggered $56 \%$ and $64 \%$ of positive skin prick test (SPT) and ELISA results, respectively, in a population of 25 date palm-allergic patients [34]. As in the Chenopodium population mentioned above, the results of Western blots exhibited several other bands in addition to a 14.4-kDa band (supposedly profilin), thus compromising the real clinical impact of profilin.

Only 1 classic report considers the impact of profilin sensitization using a purified rBet $\mathrm{v} 2$ extract for nasal challenge [35]. In a population of 24 tree and/or grass pollenallergic patients, 10 showed $\operatorname{sIgE}$ to $\mathrm{rBet} v 2$, and 8 also presented symptoms in the specific nasal provocation challenge with rBet v 2. Despite this hint of evidence, it is generally accepted that profilin is not a relevant respiratory allergen.

\section{The Role of Profilin in Food Allergy}

Allergy to profilin-containing foodstuffs is due to primary sensitization to profilin through inhalation and subsequent development of the so-called pollen-food syndrome (PFS) [36], which is based on a type II food allergy mechanism. Most syndromes involve weed pollen (eg, Ambrosia, Chenopodium, Artemisia) and grass and birch pollens (see Table 2). Although performing an extensive review of the literature in search of profilin-linked pollen-food syndromes is beyond the scope of this manuscript, it should be borne in mind that some of the classic references supporting such syndromes might only provide hints of an association and not proper evidence, either because there is no proper identification of the causative allergen or because the patients' clinical background is missing.

The most frequent scenario is profilin recognition with little or no clinical relevance [37,38]. Given its lability in pepsin digestion [39] and thermal sensitivity [40], profilin triggers oral allergy syndrome (OAS), where symptoms involve itchiness of the lips, tongue, mouth, and throat, are self-limiting both in time and extension, and appear immediately after the intake of raw plant foods. Nevertheless, there are 2 reports of systemic reactions to lychee fruit [41] and zucchini [42], with profilin being the putative allergen that creates an exception to this rule.

Despite being considered a minor allergen, profilin is the major allergen of some plant foods, for example, melon (Cuc m 2) [43], orange [44], and soybean (Gly m 3) [45,46]. It can induce symptoms to virtually every plant food; however, allergy to melon, watermelon, citrus fruits, tomato, and banana has been reported to be a clinical marker of profilin hypersensitivity in a population of patients with OAS after ingestion of vegetables $[38,47]$.

\section{The Role of Profilin in Latex Allergy}

To assess the role of Hev b 8 in latex allergy and associated syndromes, it is of utmost importance to clarify whether a patient became sensitized to latex in the first place, or if initial sensitization was due to other sources (pollen or plant foods). At the same time, it is useful to bear in mind that Hev b 8 is present in very low amounts or even absent in natural latex rubber gloves [48].

In primarily latex-sensitized individuals, recognition of $\mathrm{Hev}$ b 8 was seen to reach $40 \%$ when a purified recombinant form of $\mathrm{rHev} \mathrm{b} 8$ was used in a selected population of patients with spina bifida and latex allergy [49]. In a recent study by 
Table 2. Plant-Food Syndromes Involving Profilin

\begin{tabular}{|c|c|c|}
\hline Syndrome $^{\mathrm{a}}$ & Pollen & Plant Food \\
\hline \multicolumn{3}{|c|}{ USA: Prevalence of profilin sensitization, $15 \%$ [98] } \\
\hline Ragweed-melon-banana [99] ${ }^{\mathrm{b}}$ & Ragweed (Ambrosia) & Cucurbitaceae (melon), Musaceae (banana) \\
\hline \multicolumn{3}{|c|}{ CENTRAL EUROPE: Prevalence of profilin sensitization, 15\%-26\% [100,101] } \\
\hline Mugwort-birch-celery [41,102-106] & Birch (Betula), Mugwort (Artemisia) & $\begin{array}{l}\text { Apiaceae (celery), lychee, carrot, anise, } \\
\text { fennel, coriander and cumin }\end{array}$ \\
\hline Birch-fruit [107] & Birch (Betula) & Banana, pineapple \\
\hline Ragweed-melon-banana $[42,108]$ & Ragweed (Ambrosia) & Cucurbitaceae (zucchini), \\
\hline \multicolumn{3}{|l|}{ Musaceae (banana) } \\
\hline Compositae-fruit [41] & Compositae (Ambrosia, Artemisia) & Lychee \\
\hline \multicolumn{3}{|c|}{ SOUTHERN EUROPE: Prevalence of profilin sensitization, 15\%-50\% [17] } \\
\hline Goosefoot-fruit $[109,110]$ & Chenopodium & $\begin{array}{l}\text { Cucurbitaceae (melon), Musaceae (banana), } \\
\text { Rosaceae (peach), Liliaeae (garlic) }\end{array}$ \\
\hline Mugwort-spice [111] & Mugwort (Artemisa) & Liliaceae (garlic) \\
\hline Mugwort-peach [112] & Mugwort (Artemisa) & Rosaceae (peach) \\
\hline Ragweed-melon [111] & Grass, weeds, and trees & Cucurbitaceae (melon, zucchini) \\
\hline $\begin{array}{l}\text { Grass/Olive-Rosaceae and several } \\
\text { fruits }[17,18,27,38,113,114]\end{array}$ & Grass and olive & $\begin{array}{l}\text { Peach, Banana, Fig, Kiwi, Melon, } \\
\text { Orange, Peach, Pineapple, Watermelon }\end{array}$ \\
\hline Plane tree-fruit [115] & Plane tree (Platanus) & $\begin{array}{l}\text { Rosaceae, other fruits, peanut, treenuts, } \\
\text { and vegetables }\end{array}$ \\
\hline
\end{tabular}

asyndromes are included in areas where they are most frequently described for didactic purposes, although some were also described in different areas, which are also included in the references. It should be taken into account that in most cases, other allergens such as Bet v 1, CCDs, or others, might play a relevant role, and it is not possible to clarify the culprit of clinical reactivity.

bStudies where profilin is suspected due to molecular weight, but without proper identification.

Vandenplas et al [50] including 82 patients with occupational asthma caused by natural rubber analyzed with a panel of 12 latex allergens, Hev b 8 was only recognized in 4 patients $(4.8 \%)$. Even though profilin was the only putative allergen in 2 of these patients, the authors still resist considering it to be clinically relevant. The presence of sIgE to Heb v 8 is usually a marker of nonrelevant sensitization. Using a 9-latex allergen platform, Schuller et al [51] detected monosensitization to latex profilin in 2 out of 14 latex-allergic patients (14.2\%) and in 19 out of 28 nonallergic, latex-sensitive patients (67.8\%). Overall, Hev b 8 is not considered to have a clinical impact in latex allergy and, according to guidelines [52], patients sensitized to this allergen alone do not need a latex-free setting during surgical procedures.

Around $30 \%$ to $50 \%$ of latex-allergic patients have IgEmediated symptoms to many plant foods [53], most frequently to avocado, banana, kiwi, chestnut, and papaya. These symptoms were first described as the latex-fruit syndrome by Blanco et al [54]. Latex class I chitinases (Hev b 6) [55] and patatin-like proteins (Hev b 7) [53] have been directly involved, and despite other allergens also being potentially involved, the role of latex profilin is questionable [56]. Generally, the sensitization to Hev b 8 found in pollen- and/or fruit-allergic patients is not based upon a primary sensitization to latex, but is most likely a cross-reactive phenomenon due to the high similarity of its sequence with profilins from other sources, ranging from $89.3 \%$ to $93.9 \%$ with Hel a 2 (sunflower profilin) and Ole e 2 (olive profilin) or $88.6 \%$ to $95.5 \%$ with Ara h 5 (peanut profilin) and Pyr c 4 (pear profilin), respectively [57]. Garnier et al [58] reported 130 patients with positive sIgE to natural rubber latex, 97 of whom were latex-allergic. Among the 33 non-latex-allergic patients, 30 had food allergy, pollen allergy, or both, and 26 were monosensitized to rHev b 8 . In contrast, in a subset of 46 latex-allergic patients without pollen allergy, only 1 displayed SIgE for $\mathrm{rHev}$ b 8 , although he was food-allergic. This evidence reinforces the lack of impact of rHev b 8 positivity on latex allergy in fruit/pollen-allergic patients.

\section{The Shift in the Perception of Profilin}

Previously, profilin was shown to be a prevalent panallergen that is seemingly unable to unleash remarkable food allergic reactions and does not induce respiratory symptoms or latex allergy. However, in recent years, several publications have raised significant doubts about some of these concepts, leading to the belief that profilin is an allergen that should no longer be overlooked.

\section{Profilin, a Marker of Severity and Clinical Course}

Large epidemiological studies analyzing molecular recognition in pollen from different areas of Spain have shown profilin to be a marker of disease severity and polysensitization 
in grass allergy [17-19]. In the aforementioned population of 146 olive-allergic patients, sensitization to Ole e 2 was statistically associated with asthma (OR, 2.2; 95\%CI, 0.9-5.1; $P=.04$ ), although the confidence interval includes the null effect [22]. Similarly, in a cohort of 1271 pollen-allergic children, of whom 296 (23\%) were sensitized to profilin, sensitization to $\mathrm{rPhl} \mathrm{p} 12$ was statistically associated with longer disease duration and OAS to plant foods, but not with more severe disease [21].

Given the cross-sectional design of previous studies, stronger evidence of profilin as a marker of long-term allergic disease could only be provided by longitudinal studies, such as that of Hatzler et al [59], where a group of 820 newborns were followed until the age of 13 years. Serum sampling and clinical evaluation of all patients were performed regularly, and the authors found that in the 177 patients who finally developed seasonal allergic rhinitis to grass, profilin sensitization invariably appeared in the latter stages of the disease course and never as an early marker, thus supporting its role as an indicator of longer-term disease.

Taking an opposite approach, that is, from clinical behavior to molecular recognition, a subgroup of pediatric patients [21] were assessed for molecular characterization according to a predefined clinical profile. The authors selected 300 pollenallergic children who reported OAS within 5 minutes of ingestion of pollen-related foods and were diagnosed with PFS [60]. IgE antibodies to PR-10 (rBet v 1), LTP (rPru p 3), and timothy grass profilin ( $\mathrm{rPhl} \mathrm{p} \mathrm{12)} \mathrm{were} \mathrm{determined} \mathrm{to}$ classify the patients. A cluster analysis revealed 2 profilinrelated clinical endotypes. One group comprised 63 profilinmonosensitized children whose main distinctive characteristics were as follows: sensitization to grass, plane, olive, and plantain pollen; OAS caused by peach, kiwi, banana, and fruits from the Cucurbitaceae family; and a high frequency of asthma. The other, a more interesting group, included 85 children, in whom more than 1 panallergen (38\% profilin-sensitized) was detected. These patients recognized birch and grass pollen, experienced symptoms with all the plant foods studied, and had several comorbidities such as asthma, urticaria/angioedema, and atopic dermatitis. This study provides compelling evidence that profilin sensitization is itself associated with a more marked presence of asthma, and, when accompanied by other panallergens, with more severe allergic disease.

\section{A Symptomatic Aeroallergen}

The impact of profilin in respiratory allergy has traditionally been considered low or nonexistent [3], and recent clinical studies support this statement [61]. However, in recent years, isolated case reports suggest that profilin may be the culprit allergen in patients with pollinosis. Favré et al [62] report the case of a grass pollen-allergic patient who later developed symptoms during the birch pollen season with negative sIgE to rBet $v 1$, rBet $v 4$, and $\mathrm{rBet} v \mathrm{v}$, but with positive sIgE to $\mathrm{rBet}$ $\mathrm{v} 2$. The patients also had a positive nasal challenge result with nBet $v 2$, suggesting that birch pollen symptoms were produced by sensitization to Bet v 2 alone. Asero et al [63] describe the case of a 32-year-old woman with allergic rhinoconjunctivitis and positive SPT results to all whole-pollen and profilin extracts (nPho 2, purified natural date palm pollen profilin).
Surprisingly, in both ImmunoCAP and ISAC, all major pollen allergens were only weakly recognized or not recognized at all, although strong positivity for profilin was detected ( $\mathrm{rPhl} \mathrm{p} \mathrm{12:}$ $12.6 \mathrm{kU}_{\mathrm{A}} / \mathrm{L}$ ), leading the authors to conclude that profilin was the most probable culprit allergen for the patient's respiratory symptoms.

The evidence suggested in these scarce case reports is reinforced by a few very well-designed studies with in vivo and ex vivo provocation tests. Núñez et al [64] demonstrated that profilin can induce ocular symptoms by performing conjunctival challenges with nPho d 2 in 2 groups of pollenallergic patients: one group comprised profilin-sensitized patients $(\mathrm{n}=17)$, and the other was a control group comprising individuals not sensitized to profilin $(n=14)$. None of the control patients reacted, while $65 \%(11 / 17)$ of the profilinsensitized patients had a positive response. Two dilutions were used ( 50 and $5 \mu \mathrm{g} / \mathrm{mL}$ ), and most of the reacting patients needed the higher dose to produce positive test results $(8 / 11)$. Ruiz et al [65] showed how profilin (nPho d 2) induced positive nasal and bronchial challenges, respectively, in $43 \%$ and $77 \%$ of a profilin-sensitized cohort $(n=23)$, but not in 5 non-profilin-sensitized pollen-allergic controls, thus providing evidence that profilin can trigger nasal and bronchial symptoms in sensitized patients. A recent publication [66] demonstrated how stimulation with Bet $\mathrm{v} 2$ and Phl p 12 induced dosedependent basophil activation in 40 Bet $v 2$-sensitized birchallergic patients.

The above-mentioned data support the notion that despite the misguided perception of clinical irrelevance, profilin acts as a clinically relevant aeroallergen. Moreover, given the ubiquity of this protein in pollens and plants, sensitized subjects might react clinically to multiple allergen sources, presenting perennial symptoms and, potentially, a more severe allergic phenotype.

\section{A not so Mild Food Allergen}

Profilin is thought to be a clinically irrelevant food allergen that mostly elicits mild symptoms, although exceptions have been reported [41,42]. No other cases of systemic profilin allergy had been reported until recently, when 9 out of a cohort of 26 grass pollen profilin-sensitized adults from an area with a high grass pollen load reported systemic reactions after ingestion of plant foods [67]. In the study, only 18 individuals ( 8 with a previously reported systemic reaction) agreed to undergo a double-blind, placebo-controlled food challenge with nPho d 2 at a maximum cumulative dose of $822.2 \mu \mathrm{g}$, which was equivalent to the profilin in $283 \mathrm{~g}$ of melon. All 18 patients reacted in the challenge (median, $81.24 \mu \mathrm{g}$; range, 0.074-821.24), and systemic symptoms were elicited in 11 patients $(61.1 \%)$, with adrenaline being used in 5 cases. The authors speculate that the very high levels of grass in the atmosphere during the pollen season (peaks of 2000 grains $/ \mathrm{m}^{3}$ and sustained levels above 300 grains $/ \mathrm{m}^{3}$ ) and the high degree of sensitization to grass allergens in the patients in this geographic area are critical determinants of their severe profilin reactivity phenotype. In 2 recent presentations delivered at the 2016 annual EAACI meeting in Vienna $[68,69]$, the authors described extensive oral mucosa remodeling together with a 10 -fold increase in effector cell sensitivity associated with severe 
food profilin-mediated reactions. This is the first evidence that the oral mucosa can be an effective route for eliciting severe food reactions, with a potential impact on sublingual immunotherapy mechanisms and evolution from respiratory to food allergy.

As previously mentioned, melon and watermelon are the foods most frequently involved in profilin-induced food allergy [63], probably because the higher $\mathrm{pH}$ of melon compared with other fruits and vegetables [67] increases profilin stability and allows for a more efficient mucosal interaction. It has yet to be elucidated why patients who previously tolerated and ingested profilin daily develop such a severe allergic phenotype after presenting with severe grass respiratory allergy. The study of this particular population, which represents a unique clinical model, may provide an opportunity to understand the evolution of allergic disease and the increasingly widespread allergy pandemic [70] and to explore new biomarker strategies in allergy.

\section{Impact of Sensitization to Profilin on the Selection of Allergen Immunotherapy}

Profilin sensitization jeopardizes diagnosis and treatment in pollen-polysensitized patients. Moreno et al [71] reported a discrepancy in $56 \%$ of allergen immunotherapy (AIT) prescriptions when 1263 pollen-allergic patients were diagnosed based on SPT to whole extracts, compared with CRD based on the major grass and olive pollen allergens. Using a similar approach, Sastre et al [72] had previously described a change in the selection of the composition of up to $54 \%$ of AIT prescriptions after CRD was applied in a group of 141 adults previously assessed only by SPT to whole extract, highlighting sensitization to profilin and polcalcin as one of the main confounding factors. Other authors have reported similar findings $[73,74]$. Nonetheless, these reports state how prescription of AIT might change after CRD and the assessment of major and minor allergens, although there are no data on whether application of CRD in selection of AIT improves efficacy or not.

Although CRD seems to be helpful in assessing the presence of major and cross-reactive allergens, it does not provide information on clinical relevance and might be of limited utility if more than 1 primary source allergen arises. In fact, it is not uncommon to detect profilin sensitization in patients who are primarily sensitized to 2 or more pollens [15]. It should also be borne in mind that sensitization to profilin has been associated with a higher prevalence of sensitization to "genuine" allergens from other pollen sources such as $\mathrm{Phl} p$ 1/5, Cup a 1, Art v 1, and Ole e 1 [21]; therefore, its presence might be considered a marker of advanced sensitization to the source, rather than just a mere finding to be ignored. Organspecific challenges may be used to resolve this issue and assess clinical relevance $[75,76]$ in polysensitized patients. However, the content of profilin in whole extracts might also obscure the real meaning of a positive test in organ-specific challenges, as has been suggested by some authors [64]. The amount of profilin in extracts used in organ-specific challenges is usually disregarded [76]; however, Ruiz et al [65] analyzed Pho d 2 content in 8 diagnostic pollen extracts (ALK-Abelló) and found that only grass preparations (Lolium and Phleum) seemed to have larger amounts of this protein
(75 and $46.1 \mu \mathrm{g} / \mathrm{vial}$ of freeze-dried extract, respectively), whereas Betula, Chenopodium, Olea, Plantago, and Salsola profilin content remained far below $5 \mu \mathrm{g} /$ vial. Compared with the major allergen content of each source per vial, the profilin percentage ranges from $0.8 \%$ for Lolium to $0.01 \%$ for Plantago. Profilin might be even less represented than shown by Ruiz et al, as seen in the results of Focke et al [77], who analyzed qualitative and quantitative allergen composition in 4 timothy grass pollen extracts and found that $\mathrm{Phl} \mathrm{p} 12$ could not be detected in any of them. In conclusion, it seems unlikely that the profilin content in challenge extracts might bias results, although better knowledge of this issue would be desirable.

\section{Treating Profilin Allergy}

The possibility of tailoring AIT at the molecular level has been speculated about for many years [78]. This approach is known as component-resolved immunotherapy. A recombinant form of Phl p 12 [79] and a mutant form of Cuc m 2 (melon profilin) [80] have been developed and proposed as candidates for profilin allergy immunotherapy. Although double-blind, placebo-controlled aeroallergen trials $[81,82]$ with $\mathrm{rPhl} \mathrm{p} 1$, $\mathrm{rPhl} \mathrm{p} 2$, rPhl p 5a, rPhl p 5b, and rPhl p 6 showed that recombinant forms are effective and safe in respiratory allergy, recombinant forms have yet to be approved for use in humans. Despite these optimistic reports, Tripodi et al [83] describe 39 different recognition patterns for the 8 Phleum allergens studied in a population of 200 grass-allergic children, and even after ruling out polcalcin and profilin, their results still led to a significant degree of mismatch in the potential composition of AIT when compared with a previously used recombinant vaccine [81]. Considering both the minor impact of profilin in respiratory allergy and the low prevalence of sensitization compared with other allergens, it seems unlikely that an rPhl p 12 AIT product will be developed, although exploratory research is under way in the field [84].

Following a more viable approach, profilin as it is in currently used in AIT products could be the best option for targeting this allergen. Asero et al [85] recently performed profilin-inhibition assays with the sera of 18 pollen-allergic profilin-sensitized patients and commercially available birch, grass, ragweed, and olive pollen AIT extracts. The authors concluded that given the high level of inhibition $(80 \%$ $90 \%$ ), these products contained large amounts of profilin and were potentially able to desensitize patients to this allergen. Nevertheless, several reasons discourage the use of current AIT products to specifically treat profilin allergy: AIT products are only standardized for major allergens [86], the differences in protein content are very wide [87], and the profilin content in allergen extracts is low [65] or undetectable [77]. Supporting these considerations, in a cohort of 33 grass-allergic patients (51\% profilin-sensitized), the levels of IgG4 for Phl p 12 were undetectable after 16 weeks of grass subcutaneous immunotherapy ( $65 \mu \mathrm{g}$ of $\mathrm{Phl}$ p 5 cumulative dose, Alutard SQ, Alk-Abello). Moreover, Phl p 1, Phl p 2, and Phl p 11 IgG4 levels were low, leading the authors to suggest that the vaccine content of all 4 allergens was also so low that it was unable to elicit induction of sIgG4 [88].

Considering both scenarios, and in accordance with suggestions by other authors [21,59], the best way to treat 
profilin sensitization/allergy may be to use preventive administration of regular AIT in early stages of pollen sensitization, as this would halt the expected progression towards higher sIgE levels and wider recognition of other allergens from the same source. Given that profilin sensitization is mainly associated with grass pollen, as evidenced by an increase in prevalence at higher intensities in the grass pollen gradient and the observation that grass extracts have the highest profilin content [65] once the primary sensitization to Phl p 1 and or Phl p 5 is confirmed, grass monotherapy is likely the best therapeutic option to treat profilin-sensitized patients in the absence of specific profilin-based therapy. Unfortunately, owing to the lack of specificity of whole extract-based diagnosis and the underuse of CRD [89], correct identification of profilin-positive grass monoallergic patients is limited, and patients are therefore treated with less efficacious extracts in the best case or placed at risk of de novo sensitizations in the worst case.

In type II food allergy, it has been hypothesized that symptoms due to cross-reactivity with its homologs in plant foods will also be reduced by administering pollen AIT with the primary allergen. Interesting publications on birch pollen-allergic patients with vegetable allergy due to the crossreactivity of PR-10 proteins (Bet v 1 homologs) show both beneficial effects $[90,91]$ and no effect $[92,93]$ in the associated food allergy despite a favorable response with respect to respiratory symptoms. The experience with profilin is far more limited, with only 2 reports of food allergy being successfully treated with AIT $[94,95]$, suggesting that pollen AIT is unable or too underpowered to treat the secondary food allergy.

Another route that has been explored to minimize the impact of profilin allergy is the production of plant foods with reduced allergenicity [96], although these proposals have not yet led to any real-world implementation. To date, the best option for treatment of profilin-induced food allergy is that recently discussed by Nucera et al [97]. In their study, 7 patients with profilin-induced PFS and OAS to a wide array of foods (median number of foods triggering symptoms, 9) were treated with an $\mathrm{nPho} 2$ extract $(50 \mu \mathrm{g} / \mathrm{mL})$ following a sublingual protocol with incremental doses up to a maximum of approximately $75 \mu \mathrm{g}$ of profilin per week. The duration of the treatment was 9 to 10 months. Treatment was very well tolerated, and in the exit double-blind, placebo-controlled food challenge with each of the offending foods, patients increased the number of vegetables they could eat from $23 \%$ to $92.9 \%$. This new approach needs further optimization, and although profilin usually induces only mild symptoms, the high number of implicated foods produces a significant burden for patients and represents an important therapeutic target.

\section{Conclusions}

Profilin plays a relevant role as sensitizer and as a confounding factor in both diagnosis and treatment of patients with pollen and plant food allergy. Its relevance in latex-allergic individuals remains low or nonexistent according to several publications. In controlled settings, profilin has proven able to induce symptoms at all levels of the respiratory tract, although it still has to be elucidated whether it can induce respiratory symptoms in real-world exposure and to which extent it contributes to symptoms. The role of profilin in the bothersome OAS to several fruits has been acknowledged in pollen-allergic patients. In addition, profilin can trigger systemic reactions to plant foods in selected populations who routinely face seasons with heavy grass pollen loads. From a more holistic perspective, sensitization to profilin has been significantly linked to more severe presentation of allergic disease. Therefore, its presence should be taken seriously by allergists, who should begin to consider it more than a mere confounding factor in patient evaluations. Despite the aforementioned relevance, there is no solid therapeutic approach to treat profilin allergy. Moreover, currently available AIT products are most probably underpowered and food immunotherapy insufficiently explored. Prevention strategies could be the best option for patients who are likely to become sensitized to profilin if they are identified at early stages of their disease.

\section{Acknowledgments}

We would like to thank Oliver Shaw for his help with the English version of the manuscript. We are thankful to Stallergenes for their support of the English language review.

\section{Funding}

This work was supported by Instituto de Salud Carlos III, cofunded by Fondo Europeo de Desarrollo Regional-FEDER for the Thematic Networks and Co-operative Research Centers: ARADyAL RD16/0006/0026, RD16/0006/0003, and RD16/0006/0015.

\section{Conflicts of Interest}

The authors declare that they have no conflicts of interest.

\section{References}

1. Gunning PW, Ghoshdastider U, Whitaker S, Popp D, Robinson RC. The evolution of compositionally and functionally distinct actin filaments. J Cell Sci. 2015 Jun 1;128(11):2009-19.

2. Witke W. The role of profilin complexes in cell motility and other cellular processes. Trends Cell Biol. 2004 Aug;14(8):461-9.

3. Santos A, Van Ree R. Profilins: mimickers of allergy or relevant allergens? Int Arch Allergy Immunol. 2011;155(3):191-204.

4. Sun T, Li S, Ren H. Profilin as a regulator of the membraneactin cytoskeleton interface in plant cells. Front Plant Sci. 2013 Dec 19:4:512.

5. Valenta $R$, Duchêne $M$, Pettenburger $K$, Sillaber $C$, Valent $P$, Bettelheim $P$, et al. Identification of profilin as a novel pollen allergen; IgE autoreactivity in sensitized individuals. Science. 1991 Aug 2;253(5019):557-60.

6. WHO/IUIS Allergen Nomenclature Home Page [Internet]. [cited 2017 Feb 28]. Available from: http://www.allergen.org/

7. Thorn KS, Christensen HE, Shigeta R, Huddler D, Shalaby L, Lindberg $U$, et al. The crystal structure of a major allergen from plants. Structure. 1997 Jan 15;5(1):19-32

8. Fedorov AA, Ball T, Mahoney NM, Valenta R, Almo SC. The molecular basis for allergen cross-reactivity: crystal structure 
and IgE-epitope mapping of birch pollen profilin. Structure. 1997 Jan 15;5(1):33-45.

9. Radauer $C$, Willerroider $M$, Fuchs $H$, Hoffmann-Sommergruber $K$, Thalhamer J, Ferreira $F$, et al. Cross-reactive and speciesspecific immunoglobulin $E$ epitopes of plant profilins: an experimental and structure-based analysis. Clin Exp Allergy. 2006 Jul;36(7):920-9.

10. Leitner A, Jensen-Jarolim E, Grimm R, Wüthrich B, Ebner $H$, Scheiner $O$, et al. Allergens in pepper and paprika. Immunologic investigation of the celery-birch-mugwort-spice syndrome. Allergy. 1998 Jan;53(1):36-41.

11. Tordesillas L, Pacios LF, Palacín A, Cuesta-Herranz J, Madero M, Díaz-Perales A. Characterization of lgE epitopes of Cuc m 2 , the major melon allergen, and their role in cross-reactivity with pollen profilins. Clin Exp Allergy. 2010 Jan;40(1):174-81.

12. Elfman L, Svensson M, Lidholm J, Pauli G, Valenta R. Different profiles in specific IgE to $r$ Bet $\vee 1$ and rBet $\vee 2$ in patients allergic to birch pollen from six countries. Int Arch Allergy Immunol. 1997 Jul;113(1-3):249-51.

13. Vallverdú A, García-Ortega P, Martínez J, Martínez A, Esteban $\mathrm{MI}$, de Molina $\mathrm{M}$, et al. Mercurialis annua: characterization of main allergens and cross-reactivity with other species. Int Arch Allergy Immunol. 1997 Apr;112(4):356-64.

14. D'Amato G, Cecchi L, Bonini S, Nunes C, Annesi-Maesano I, Behrendt $\mathrm{H}$, et al. Allergenic pollen and pollen allergy in Europe. Allergy. 2007 Sep;62(9):976-90.

15. Villalta $D$, Asero R. Analysis of the allergenic profile of patients hypersensitive to pollen pan-allergens living in two distinct areas of northern Italy. Eur Ann Allergy Clin Immunol. 2011 Mar;43(2):54-7.

16. Rossi RE, Melioli G, Monasterolo G, Harwanegg C, Rossi L, Canonica GW, et al. Sensitization profiles in polysensitized patients from a restricted geographical area: further lessons from multiplexed component resolved diagnosis. Eur Ann Allergy Clin Immunol. 2011 Dec;43(6):171-5.

17. Barber D, de la Torre F, Feo F, Florido F, Guardia P, Moreno C, et al. Understanding patient sensitization profiles in complex pollen areas: a molecular epidemiological study. Allergy. 2008 Nov;63(11):1550-8.

18. Barber $D$, de la Torre F, Lombardero M, Antépara I, Colas C, Dávila I, et al. Component-resolved diagnosis of pollen allergy based on skin testing with profilin, polcalcin and lipid transfer protein pan-allergens. Clin Exp Allergy. 2009 Nov;39(11):1764-73.

19. Barber D, Díaz-Perales A, Villalba M, Chivato T. Challenges for allergy diagnosis in regions with complex pollen exposures. Curr Allergy Asthma Rep. 2015 Feb; 15(2):496.

20. LedesmaA, Rodríguez R, Villalba M. Olive-pollen profilin. Molecular and immunologic properties. Allergy. 1998 May;53(5):520-6.

21. Asero R, Tripodi S, Dondi A, Di Rienzo Businco A, Sfika I, Bianchi $A$, et al. Prevalence and Clinical Relevance of IgE Sensitization to Profilin in Childhood: A Multicenter Study. Int Arch Allergy Immunol. 2015;168(1):25-31.

22. Quiralte J, Llanes E, Barral P, Arias de Saavedra JM, Sáenz de San Pedro B, Villalba M, et al. Ole e 2 and Ole e 10: new clinical aspects and genetic restrictions in olive pollen allergy. Allergy. 2005 Mar;60(3):360-5.

23. Barber D, Moreno C, Ledesma A, Serrano P, Galán A, Villalba $M$, et al. Degree of olive pollen exposure and sensitization patterns. Clinical implications. J Investig Allergol Clin Immunol. 2007;17 Suppl 1:11-6.

24. Fernández-Rivas M, Bolhaar S, González-Mancebo E, Asero R, van Leeuwen A, Bohle B, et al. Apple allergy across Europe: how allergen sensitization profiles determine the clinical expression of allergies to plant foods. J Allergy Clin Immunol. 2006 Aug; 118(2):481-8.

25. Andersen M-BS, Hall S, Dragsted LO. Identification of european allergy patterns to the allergen families PR-10, LTP, and profilin from Rosaceae fruits. Clin Rev Allergy Immunol. 2011 Aug;41(1):4-19.

26. Villalta D, Asero R. Sensitization to the pollen pan-allergen profilin. Is the detection of immunoglobulin $E$ to multiple homologous proteins from different sources clinically useful? J Investig Allergol Clin Immunol. 2010;20(7):591-5.

27. Asero R, Monsalve R, Barber D. Profilin sensitization detected in the office by skin prick test: a study of prevalence and clinical relevance of profilin as a plant food allergen. Clin Exp Allergy. 2008 Jun;38(6):1033-7.

28. Orovitg A, Guardia P, Barber $D$, de la Torre F, Rodríguez $R$, Villalba $M$, et al. Enhanced diagnosis of pollen allergy using specific immunoglobulin $\mathrm{E}$ determination to detect major allergens and panallergens. J Investig Allergol Clin Immunol. 2011;21(4):253-9.

29. Asero R, Jimeno L, Barber D. Component-resolved diagnosis of plant food allergy by SPT. Eur Ann Allergy Clin Immunol. 2008 Dec;40(4):115-21.

30. Matricardi PM, Kleine-Tebbe J, Hoffmann HJ, Valenta R, Hilger C, Hofmaier S, et al. EAACI Molecular Allergology User's Guide. Pediatr Allergy Immunol. 2016 May;27 Suppl 23:1-250.

31. Asero R, Jimeno L, Barber D. Preliminary results of a skin prick test-based study of the prevalence and clinical impact of hypersensitivity to pollen panallergens (polcalcin and profilin). J Investig Allergol Clin Immunol. 2010;20(1):35-8.

32. Barderas R, Villalba M, Pascual CY, Batanero $E$, Rodríguez R. Profilin (Che a 2) and polcalcin (Che a 3) are relevant allergens of Chenopodium album pollen: isolation, amino acid sequences, and immunologic properties. J Allergy Clin Immunol. 2004 Jun;113(6):1192-8.

33. Nouri HR, Sankian M, Vahedi F, Afsharzadeh D, Rouzbeh L, Moghadam $M$, et al. Diagnosis of Chenopodium album allergy with a cocktail of recombinant allergens as a tool for componentresolved diagnosis. Mol Biol Rep. 2012 Mar;39(3):3169-78.

34. Asturias JA, Ibarrola I, Fernández J, Arilla MC, González-Rioja $R$, Martínez A. Pho d 2, a major allergen from date palm pollen, is a profilin: cloning, sequencing, and immunoglobulin E cross-reactivity with other profilins. Clin Exp Allergy. 2005 Mar;35(3):374-81.

35. Niederberger $V$, Stübner $P$, Spitzauer $S$, Kraft $D$, Valenta $R$, Ehrenberger $K$, et al. Skin test results but not serology reflect immediate type respiratory sensitivity: a study performed with recombinant allergen molecules. J Invest Dermatol. 2001 Oct;117(4):848-51.

36. Fernández-Rivas M. Fruit and vegetable allergy. Chem Immunol Allergy. 2015;101:162-70.

37. Wensing $M$, Akkerdaas $J H$, van Leeuwen WA, Stapel SO, Bruijnzeel-Koomen CAFM, Aalberse RC, et al. IgE to Bet v 1 and profilin: cross-reactivity patterns and clinical relevance. J Allergy Clin Immunol. 2002 Sep;110(3):435-42. 
38. Asero R, Mistrello G, Roncarolo D, Amato S, Zanoni D, Barocci $F$, et al. Detection of clinical markers of sensitization to profilin in patients allergic to plant-derived foods. J Allergy Clin Immunol. 2003 Aug;112(2):427-32.

39. Jankiewicz A, Baltes W, Bögl KW, Dehne LI, Jamin A, Hoffmann $A$, et al. In vitro study of the gastrointestinal stability of celery allergens. J Sci Food Agric. 1997;9(3):203-17.

40. Jankiewicz A, Baltes W, Bögl KW, Dehne LI, Jamin A, Hoffmann $A$, et al. Influence of food processing on the immunochemical stability of celery allergens. J Sci Food Agric. 1997;75(3):359-70.

41. Fäh J, Wüthrich B, Vieths $S$. Anaphylactic reaction to lychee fruit: evidence for sensitization to profilin. Clin Exp Allergy. 1995 Oct;25(10):1018-23.

42. Reindl J, Anliker MD, Karamloo F, Vieths S, Wüthrich B. Allergy caused by ingestion of zucchini (Cucurbita pepo): characterization of allergens and cross-reactivity to pollen and other foods. J Allergy Clin Immunol. 2000 Aug; 106(2):379-85.

43. López-Torrejón G, Crespo JF, Sánchez-Monge R, SánchezJiménez $M$, Alvarez J, Rodriguez J, et al. Allergenic reactivity of the melon profilin Cuc $\mathrm{m} 2$ and its identification as major allergen. Clin Exp Allergy. 2005 Aug;35(8):1065-72.

44. López-Torrejón G, Ibáñez MD, Ahrazem 0, Sánchez-Monge R, Sastre J, Lombardero $\mathrm{M}$, et al. Isolation, cloning and allergenic reactivity of natural profilin Cit $s$ 2, a major orange allergen. Allergy. 2005 Nov;60(11):1424-9.

45. Rihs HP, Chen Z, Ruëff F, Petersen A, Rozynek $P$, Heimann $H$, et al. IgE binding of the recombinant allergen soybean profilin ( $\mathrm{rGly} \mathrm{m} 3$ ) is mediated by conformational epitopes. J Allergy Clin Immunol. 1999 Dec;104(6):1293-301.

46. Mittag D, Vieths S, Vogel L, Becker W-M, Rihs H-P, Helbling $A$, et al. Soybean allergy in patients allergic to birch pollen: clinical investigation and molecular characterization of allergens. J Allergy Clin Immunol. 2004 Jan;113(1):148-54.

47. Asero R, Mistrello $G$, Amato $S$. The nature of melon allergy in ragweed-allergic subjects: A study of 1000 patients. Allergy Asthma Proc. 2011 Feb;32(1):64-7.

48. Yeang H-Y, Hamilton RG, Bernstein DI, Arif S a. M, Chow K-S, Loke Y-H, et al. Allergen concentration in natural rubber latex. Clin Exp Allergy. 2006 Aug;36(8):1078-86.

49. Nieto A, Mazón A, Boquete $M$, Carballada F, Asturias JA, Martínez J, et al. Assessment of profilin as an allergen for latex-sensitized patients. Allergy. 2002 Sep;57(9):776-84.

50. Vandenplas O, Froidure A, Meurer U, Rihs H-P, Rifflart C, Soetaert $\mathrm{S}$, et al. The role of allergen components for the diagnosis of latexinduced occupational asthma. Allergy. 2016 Jun;71(6):840-9.

51. Schuler S, Ferrari G, Schmid-Grendelmeier P, Harr T. Microarraybased component-resolved diagnosis of latex allergy: isolated IgE-mediated sensitization to latexprofilin Hev b8 may act as confounder. Clin Transl Allergy. 2013 Mar 28;3(1):11.

52. Quercia O, Stefanini GF, Scardovi A, Asero R. Patients monosensitised to Hev b 8 (Hevea brasiliensis latex profilin) may safely undergo major surgery in a normal (non-latex safe) environment. Eur Ann Allergy Clin Immunol. 2009 Aug;41(4):112-6.

53. Wagner $\mathrm{S}$, Breiteneder $\mathrm{H}$. The latex-fruit syndrome. Biochem Soc Trans. 2002 Nov;30(Pt 6):935-40.

54. Blanco C, Carrillo T, Castillo R, Quiralte J, Cuevas M. Latex allergy: clinical features and cross-reactivity with fruits. Ann Allergy. 1994 Oct;73(4):309-14.
55. Sánchez-Monge R, Blanco C, Perales AD, Collada C, Carrillo T, Aragoncillo $C$, et al. Class I chitinases, the panallergens responsible for the latex-fruit syndrome, are induced by ethylene treatment and inactivated by heating. J Allergy Clin Immunol. 2000 Jul; 106(1 Pt 1):190-5.

56. Cabañes $N$, Igea JM, de la Hoz B, Agustín $P$, Blanco $C$, Domínguez J, et al. Latex allergy: Position Paper. J Investig Allergol Clin Immunol. 2012;22(5):313-330.

57. Ganglberger $E$, Radauer $C$, Wagner $S$, Ríordáin $G$, Beezhold $\mathrm{DH}$, Brehler R, et al. Hev b 8, the Hevea brasiliensis latex profilin, is a cross-reactive allergen of latex, plant foods and pollen. Int Arch Allergy Immunol. 2001 Jul;125(3):216-27.

58. Garnier L, Selman L, Rouzaire P, Bouvier M, Roberts O, Bérard $F$, et al. Molecular allergens in the diagnosis of latex allergy. Eur Ann Allergy Clin Immunol. 2012 Apr;44(2):73-9.

59. Hatzler L, Panetta V, Lau S, Wagner P, Bergmann RL, Illi S, et al. Molecular spreading and predictive value of preclinical $\lg$ E response to Phleum pratense in children with hay fever. J Allergy Clin Immunol. 2012 Oct; 130(4):894-901.e5.

60. Mastrorilli C, Tripodi S, Caffarelli C, Perna S, Di Rienzo-Businco A, Sfika I, et al. Endotypes of pollen-food syndrome in children with seasonal allergic rhinoconjunctivitis: a molecular classification. Allergy. 2016 Aug;71(8):1181-91.

61. San Nicoló M, Braun T, Eder K, Berghaus A, Gröger M. Clinical Relevance of $\mathrm{IgE}$ to Profilin and/or Polcalcin in Pollen-Sensitized Patients. Int Arch Allergy Immunol. 2016;169(2):101-7.

62. Metz Favre C, Pauli G, Castro L, Valenta R, De Blay F. Bet v 2 Responsibility in Birch-Induced Symptoms. J Allergy Ther. 2014;5:169-70.

63. Asero R, Villalta D. Profilin may be a primary airborne sensitizer: a case report. J Investig Allergol Clin Immunol. 2013;23(2):134-5.

64. Núñez R, Carballada F, Lombardero M, Jimeno L, Boquete M. Profilin as an aeroallergen by means of conjunctival allergen challenge with purified date palm profilin. Int Arch Allergy Immunol. 2012;158(2):115-9.

65. Ruiz-García M, García Del Potro M, Fernández-Nieto M, Barber D, Jimeno-Nogales L, Sastre J. Profilin: a relevant aeroallergen? J Allergy Clin Immunol. 2011 Aug; 128(2):416-8.

66. Wölbing F, Kunz J, KempfWE, Grimmel C, Fischer J, Biedermann $T$. The clinical relevance of birch pollen profilin cross-reactivity in sensitized patients. Allergy. 2016 Sep 2;

67. Alvarado MI, Jimeno L, De La Torre F, Boissy P, Rivas B, Lázaro $M J$, et al. Profilin as a severe food allergen in allergic patients overexposed to grass pollen. Allergy. 2014 Dec;69(12):16106.

68. Escribese M, Rosace D, Fernandez P. Immunological differences in oral mucosa and effector cell sensitivity in patients with different severity degree of profilin mediated food reactions. Allergy. 2016;\$102:73.

69. Rosace D, Escribese M, Fernandez P. Severe profilin mediated food reactions correlate with e oral mucosa integrity. Allergy. 2016;5102:161.

70. Barber Hernández D. Could Profilin Be a 'Canary in a Coal Mine' of the Increasing Allergy Epidemic? Int Arch Allergy Immunol. 2015;168(1):1-2.

71. Moreno C, Justicia JL, Quiralte J, Moreno-Ancillo A, IglesiasCadarso $A$, Torrecillas $M$, et al. Olive, grass or both? Molecular diagnosis for the allergen immunotherapy 
selection in polysensitized pollinic patients. Allergy. 2014 Oct;69(10):1357-63.

72. Sastre J, Landivar ME, Ruiz-García M, Andregnette-Rosigno MV, Mahillo I. How molecular diagnosis can change allergenspecific immunotherapy prescription in a complex pollen area. Allergy. 2012 May;67(5):709-11.

73. Stringari G, Tripodi S, Caffarelli C, Dondi A, Asero R, Di Rienzo Businco $A$, et al. The effect of component-resolved diagnosis on specific immunotherapy prescription in children with hay fever. J Allergy Clin Immunol. 2014 Jul;134(1):75-81.

74. Letrán A, Espinazo M, Moreno F. Measurement of IgE to pollen allergen components is helpful in selecting patients for immunotherapy. Ann Allergy Asthma Immunol. 2013 Oct;111(4):295-7.

75. Hamilton RG. Provocation tests with objective measures remain more diagnostic than surrogate immunoglobulin $E$ antibody measures of sensitization. Clin Exp Allergy. 2011 Aug:41(8):1048-9.

76. Huss-Marp J, Darsow U, Brockow K, Pfab F, Weichenmeier I, Schober W, et al. Can immunoglobulin E-measurement replace challenge tests in allergic rhinoconjunctivits to grass pollen? Clin Exp Allergy. 2011 Aug;41(8):1116-24.

77. Focke M, Marth K, Flicker S, Valenta R. Heterogeneity of commercial timothy grass pollen extracts. Clin Exp Allergy. 2008 Aug;38(8):1400-8.

78. Valenta $R$, Lidholm J, Niederberger $V$, Hayek B, Kraft D, Grönlund $H$. The recombinant allergen-based concept of component-resolved diagnostics and immunotherapy (CRD and CRIT). Clin Exp Allergy. 1999 Jul;29(7):896-904.

79. Westritschnig K, Linhart B, Focke-Tejkl M, Pavkov T, Keller W, Ball T, et al. A hypoallergenic vaccine obtained by tail-to-head restructuring of timothy grass pollen profilin, Phl p 12, for the treatment of cross-sensitization to profilin. J Immunol Baltim Md 1950. 2007 Dec 1;179(11):7624-34.

80. Tordesillas L, Gamboa P, Sanz ML, Palacín A, Gómez-Casado C, Cuesta-Herranz J, et al. A mutant of the major melon allergen, Cuc $m$ 2, with reduced IgE binding capacity is a good candidate for specific immunotherapy. Mol Immunol. 2011 Dec;49(3):504-11.

81. Jutel $M$, Jaeger $L$, Suck $R$, Meyer $H$, Fiebig $H$, Cromwell $O$. Allergen-specific immunotherapy with recombinant grass pollen allergens. J Allergy Clin Immunol. 2005 Sep;116(3):608-13.

82. Klimek L, Schendzielorz P, Pinol R, Pfaar O. Specific subcutaneous immunotherapy with recombinant grass pollen allergens: first randomized dose-ranging safety study. Clin Exp Allergy. 2012 Jun;42(6):936-45.

83. Tripodi $S$, Frediani $T$, Lucarelli $S$, Macrì $F$, Pingitore $G, D i$ Rienzo Businco A, et al. Molecular profiles of IgE to Phleum pratense in children with grass pollen allergy: implications for specific immunotherapy. J Allergy Clin Immunol. 2012 Mar;129(3):834-9.e8.

84. Roozbeh Nasiraie L, Tabatabaie F, Sankian M, Shahidi F, Varasteh A. Construction of a recombinant allergen-producing probiotic bacterial strain: Introduction of a new line for a live oral vaccine against Chenopodium album pollen allergy. Rep Biochem Mol Biol. 2013 Oct;2(1):16-27.

85. Asero R, Mistrello G, Amato S. Detection of pan-allergens in commercial pollen extracts for allergen immunotherapy. Ann Allergy Asthma Immunol. 2016 Aug;117(2):180-5.
86. Guideline on the Clinical Development of Products for Specific Immunotherapy for the Treatment of Allergic Diseases. - WC500003605.pdf [Internet]. [Cited 2017 Apr 17]. Available at: http://www.ema.europa.eu/docs/ en_GB/document_library/Scientific_guideline/2009/09/ WC500003605.pdf

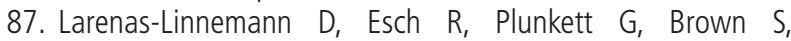
Maddox D, Barnes $C$, et al. Maintenance dosing for sublingual immunotherapy by prominent European allergen manufacturers expressed in bioequivalent allergy units. Ann Allergy Asthma Immunol. 2011 Nov; 107(5):448-58.e3.

88. Rossi RE, Monasterolo G. Evaluation of recombinant and native timothy pollen ( $\mathrm{rPhl} p \mathrm{1}, 2,5,6,7,11,12$ and $\mathrm{nPhl}$ p 4)- specific IgG4 antibodies induced by subcutaneous immunotherapy with timothy pollen extract in allergic patients. Int Arch Allergy Immunol. 2004 Sep;135(1):44-53.

89. Caminati M, Savi E, Villalta D, Passalacqua G, Triggiani M, Senna G. Component resolved diagnosis (CRD): how much is it presently used by Italian allergists? Eur Ann Allergy Clin Immunol. 2014 May;46(3):106-8.

90. Bolhaar STHP, Tiemessen MM, Zuidmeer L, van Leeuwen $A$, Hoffmann-Sommergruber K, Bruijnzeel-Koomen C a. FM, et al. Efficacy of birch-pollen immunotherapy on cross-reactive food allergy confirmed by skin tests and double-blind food challenges. Clin Exp Allergy. 2004 May;34(5):761-9.

91. Bucher $X$, Pichler WJ, Dahinden CA, Helbling A. Effect of tree pollen specific, subcutaneous immunotherapy on the oral allergy syndrome to apple and hazelnut. Allergy. 2004 Dec;59(12):1272-6.

92. Hansen KS, Khinchi MS, Skov PS, Bindslev-Jensen C, Poulsen LK, Malling H-J. Food allergy to apple and specific immunotherapy with birch pollen. Mol Nutr Food Res. 2004 Nov;48(6):441-8.

93. Kinaciyan T, Jahn-Schmid B, Radakovics A, Zwölfer B, Schreiber C, Francis JN, et al. Successful sublingual immunotherapy with birch pollen has limited effects on concomitant food allergy to apple and the immune response to the Bet $v 1$ homolog Mal d 1. J Allergy Clin Immunol. 2007 Apr;119(4):937-43.

94. Asero R. Fennel, cucumber, and melon allergy successfully treated with pollen-specific injection immunotherapy. Ann Allergy Asthma Immunol. 2000 Apr;84(4):460-2.

95. Kelso JM, Jones RT, Tellez R, Yunginger JW. Oral allergy syndrome successfully treated with pollen immunotherapy. Ann Allergy Asthma Immunol. 1995 May;74(5):391-6.

96. Le LQ, Mahler V, Lorenz Y, Scheurer S, Biemelt S, Vieths S, et al. Reduced allergenicity of tomato fruits harvested from Lyc e 1-silenced transgenic tomato plants. J Allergy Clin Immunol. 2006 Nov; 118(5):1176-83.

97. Nucera E, Aruanno A, Rizzi A, Pecora V, Patriarca G, Buonomo A, et al. Profilin desensitization: A case series. Int J Immunopathol Pharmacol. 2016 Sep;29(3):529-36.

98. Nolte M, Barber D, Maloney J, Li Z, Kaur A, Galan A, et al. Timothy specific IgE levels are associated with efficacy and safety of timothy grass sublingual immunotherapy tablet. Ann Allergy Asthma Immunol Off Publ Am Coll Allergy Asthma Immunol. 2015 Dec;115(6):509-15.e2.

99. Enberg RN, Leickly FE, McCullough J, Bailey J, Ownby DR. Watermelon and ragweed share allergens. J Allergy Clin Immunol. 1987 Jun;79(6):867-75. 
100. Geroldinger-Simic M, Zelniker T, Aberer W, Ebner C, Egger C, Greiderer $A$, et al. Birch pollen-related food allergy: clinical aspects and the role of allergen-specific $\lg \mathrm{E}$ and $\lg \mathrm{G} 4$ antibodies. J Allergy Clin Immunol. 2011 Mar;127(3):61622.e1.

101. Tresch S, Holzmann D, Baumann S, Blaser K, Wüthrich B, Crameri $R$, et al. In vitro and in vivo allergenicity of recombinant Bet $v 1$ compared to the reactivity of natural birch pollen extract. Clin Exp Allergy. 2003 Aug;33(8):1153-8.

102. Ebner $C$, Hirschwehr R, Bauer L, Breiteneder H, Valenta R, Ebner $\mathrm{H}$, et al. Identification of allergens in fruits and vegetables: IgE cross-reactivities with the important birch pollen allergens Bet v 1 and Bet v 2 (birch profilin). J Allergy Clin Immunol. 1995 May;95(5 Pt 1):962-9.

103. Scheurer S, Wangorsch A, Haustein D, Vieths S. Cloning of the minor allergen Api g 4 profilin from celery (Apium graveolens) and its cross-reactivity with birch pollen profilin Bet v 2. Clin Exp Allergy. 2000 Jul;30(7):962-71.

104. Lüttkopf D, Ballmer-Weber BK, Wüthrich B, Vieths S. Celery allergens in patients with positive double-blind placebocontrolled food challenge. J Allergy Clin Immunol. 2000 Aug;106(2):390-9.

105. Ballmer-Weber BK, Wüthrich B, Wangorsch A, Fötisch K, Altmann F, Vieths S. Carrot allergy: double-blinded, placebocontrolled food challenge and identification of allergens. J Allergy Clin Immunol. 2001 Aug; 108(2):301-7.

106. Jensen-Jarolim $E$, Leitner $A$, Hirschwehr $R$, Kraft $D$, Wüthrich $B$, Scheiner 0 , et al. Characterization of allergens in Apiaceae spices: anise, fennel, coriander and cumin. Clin Exp Allergy. 1997 Nov;27(11):1299-306.

107. Reindl J, Rihs HP, Scheurer S, Wangorsch A, Haustein D, Vieths $S$. IgE reactivity to profilin in pollen-sensitized subjects with adverse reactions to banana and pineapple. Int Arch Allergy Immunol. 2002 Jun;128(2):105-14.

108. Grob M, Reindl J, Vieths S, Wüthrich B, Ballmer-Weber BK. Heterogeneity of banana allergy: characterization of allergens in banana-allergic patients. Ann Allergy Asthma Immunol. 2002 Nov;89(5):513-6.
109. Callejo A, Sanchís ME, Armentia A, Moneoa I, Fernández A. A new pollen-fruit cross-reactivity. Allergy. 2002 Nov;57(11): 1088-9.

110. Añibarro B, Fontela JL, De La Hoz F. Occupational asthma induced by garlic dust. J Allergy Clin Immunol. 1997 Dec;100(6 Pt 1):734-8.

111. Rodriguez-Perez R, Crespo JF, Rodríguez J, Salcedo G. Profilin is a relevant melon allergen susceptible to pepsin digestion in patients with oral allergy syndrome. J Allergy Clin Immunol. 2003 Mar;111(3):634-9.

112. Cuesta-Herranz J, Lázaro M, MartínezA, Figueredo E, Palacios R, de-Las-Heras $M$, et al. Pollen allergy in peach-allergic patients: sensitization and cross-reactivity to taxonomically unrelated pollens. J Allergy Clin Immunol. 1999 Sep;104(3 Pt 1):688-94.

113. van Ree $R$, Fernández-Rivas $M$, Cuevas $M$, van Wijngaarden M, Aalberse RC. Pollen-related allergy to peach and apple: an important role for profilin. J Allergy Clin Immunol. 1995 Mar;95(3):726-34.

114. Daschner A, Crespo JF, Pascual CY. Specific IgE to recombinant vegetal panallergen (rBet $\vee 2$ ) and fruit allergy in pollinic patients. Allergy. 1998 Jun;53(6):614-8.

115. Enrique $E$, Alonso R, Bartolomé B, San Miguel-Moncín $M$, Bartra J, Fernández-Parra $B$, et al. IgE reactivity to profilin in Platanus acerifolia pollen-sensitized subjects with plantderived food allergy. J Investig Allergol Clin Immunol. 2004; 14(4):335-42.

\section{- Pablo Rodríguez del Río}

Servicio de Alergia de Hospital Infantil Universitario Niño Jesús

Avenida de Menéndez Pelayo número 65

28009 Madrid, Spain

E-mail: prrio@yahoo.es 